\title{
Human Insulin-like Growth Factor I Receptor Function in Pituitary Cells Is Suppressed by a Dominant Negative Mutant
}

\author{
Diane Prager, Hironori Yamasaki, Matthias M. Weber, Saba Gebremedhin, and Shlomo Melmed \\ Department of Medicine, Cedars-Sinai Medical Center-UCLA School of Medicine, Los Angeles, California 90048
}

\begin{abstract}
Hybrid receptors were studied in GC rat pituitary cells overexpressing either wild-type ${ }^{950} \mathrm{Tyr}$ (WT) human insulin-like growth factor I (IGF-I) receptors or mutant human IGF-I receptors truncated at position 952 in the $\beta$ subunit transmembrane region ( $\left.{ }^{952} \mathrm{STOP}\right) .{ }^{125} \mathrm{I}-\mathrm{IGF}-\mathrm{I}$ binding was increased in both ${ }^{950}$ Tyr (WT) (14-fold) and truncated human IGF-I receptor $\left({ }^{952} \mathrm{STOP}\right)$ stable transfectants $(50$-fold), when compared to untransfected cells that contained endogenous rat IGF-I receptors. Metabolic cell labeling followed by immunoprecipitation with monoclonal $\alpha$ and $\beta$ subunit-specific antibodies revealed the presence of hybrid rat/truncated human receptors, truncated transfected human receptors, and WT human IGF-I holotetramers. Both mutant and hybrid receptors were degraded slower than ${ }^{950}$ Tyr (WT) receptors (> 16 h). Despite their markedly increased ligand binding and prolonged receptor half-life, ${ }^{952}$ STOP transfectants failed to transduce the IGF-I signal to suppress growth hormone (GH). Also, they neither underwent autophosphorylation nor phosphorylated endogenous proteins. The expected suppression of $\mathrm{GH}$ by endogenous rat IGF-I receptors was completely abrogated in ${ }^{952}$ STOP transfectants $(P<0.001$ compared to untransfected cells $)$. Mutant ${ }^{952}$ STOP cells were therefore completely devoid of biological signaling to $\mathrm{GH}$ despite the presence of endogenous rat IGF-I receptors. Thus mutant IGF-I receptors block ligandmediated endogenous rat IGF-I signaling by functioning as a dominant negative forming nonfunctional human/rat hybrid receptors. Defective IGF-I receptors may function therefore as dominant negative phenotypes which suppress normal receptor responses in pituitary cells. (J. Clin. Invest. 1992. 90:21172122.) Key words: growth hormone $\bullet$ insulin-like growth factor I receptor $\bullet$ pituitary
\end{abstract}

\section{Introduction}

Insulin-like growth factor I (IGF-I ), ${ }^{1}$ a target growth factor for growth hormone $(\mathrm{GH})$ action, suppresses pituitary $\mathrm{GH}$ gene

Address reprint requests to Dr. Melmed, Division of Endocrinology and Metabolism, 8700 Beverly Blvd., B131, Los Angeles, CA 90048. 1992.

Received for publication 18 May 1992 and in revised form $15 \mathrm{July}$

1. Abbreviations used in this paper: $\mathrm{GH}$, growth hormone; IGF-I, insulin-like growth factor I; WT, wild-type (receptor).

J. Clin. Invest.

(C) The American Society for Clinical Investigation, Inc.

$0021-9738 / 92 / 11 / 2117 / 06 \$ 2.00$

Volume 90, November 1992, 2117-2122 expression $(1,2)$. The abundance of somatotroph IGF-I receptors appears to be a major determinant of $\mathrm{GH}$ secretion in response to IGF-I (3). Defects in endocrine receptors may underly several pathophysiologic states. Heterozygote individuals expressing both wild-type (WT) and mutant thyroid hormone receptors and wild-type or tyrosine kinase defective surface insulin receptors have been described (4-7). These patients exhibit thyroid hormone or insulin resistance, respectively. $\mathrm{Re}-$ cent reports demonstrate that defective epidermal growth factor $(8,9)$, platelet-derived growth factor $(10)$, fibroblast growth factor (11), and c-kit (12) receptors function as dominant negative mutants suppressing the response of normal receptors in the same cell. These growth factor receptors dimerize in the presence of ligand and are noncovalently associated. In contrast, insulin and IGF-I receptors are covalently linked by disulfide bonds independent of ligand binding. Overexpression of a truncated insulin receptor lacking kinase activity inhibited insulin-stimulated tyrosine phosphorylation of putative substrates and results in diminished sensitivity of transfected cells to insulin (13). Wild-type-mutant receptor hybrid formation offers an explanation for the observed inhibition of endogenous receptor function both in vivo and in vitro. Intact rat/human hybrid insulin receptor formation as well as intact insulin/IGF-I hybrids have been demonstrated both in vivo and in cell-free systems (14-16).

We have previously reported that overexpression of the intact ${ }^{950}$ Tyr (WT) human IGF-I receptor cDNA in rat pituitary GC cells results in enhanced responsiveness of transfectants to the IGF-I signal (17). Overexpression of site-directed mutants at position ${ }^{950} \mathrm{Tyr}$ of the human IGF-I receptor by pituitary GC cells abolishes the suppressive feedback effect of IGF-I on GH (18). The presence of endogenous insulin and IGF-I receptors in the parental GC cells raised the question of whether rat / human IGF-I hybrid receptor formation occurred in those ${ }^{950} \mathrm{Tyr}$ (WT) transfectants. To determine whether alterations in IGF-I receptor function could result from assembly of wild-type and mutant receptor subtypes, ${ }^{950} \mathrm{Tyr}$ (WT) and truncated mutant human IGF-I cDNAs were overexpressed in GC rat pituitary cells. Hybrid rat/mutant human IGF-I receptor biosynthetic half-life, autophosphorylation, phosphorylation of endogenous substrate, and pituitary signaling were tested. The results indicate that holotetramers consisting of ${ }^{950} \mathrm{Tyr}$ (WT) and mutant IGF-I half receptors possess a dominant negative effect on endogenous IGF-I receptor function.

\section{Methods}

Recombinant human IGF-I (Met-59) was kindly provided by Fujisawa Pharmaceutical Co. (Osaka, Japan). ${ }^{125}$ I-IGF-I was purchased from Amersham Corp. (Arlington Heights, IL). $\alpha$ IR 3 was purchased from 
Oncogene (Manhasset, NY). Ab1-2, a monoclonal antibody which recognizes both human and rat IGF-I receptor $\beta$ subunit, was kindly provided by Dr. K. Siddle (University of Cambridge, Cambridge, England). P-Tyr (Ab-2) anti-phosphotyrosine antibody (IgG1) was purchased from Oncogene and anti-mouse IgG was purchased from Sigma Chemical Co. (St. Louis, MO). $\left[{ }^{35} \mathrm{~S}\right]$ methionine was from ICN Biochemicals (Costa Mesa, CA).

Truncation of human IGF-I receptor. The wild-type human IGF-I receptor expression plasmid ( $p R S V-I G F I R$ ) has been previously described (18). For truncation of the human IGF-I receptor, a Sma-Hind III fragment from pRSV-IGFIR was subcloned into M13mp19. An Xba linker, 5'TGCTCTAGAGCA3', was inserted into the Sca I site present in a SmaI-Hind III IGF-I receptor cDNA fragment, resulting in an in-frame stop codon at position 952. After reintroduction of the mutant sequence into the pRSV-IGFIR vector, the construct was subjected to dideoxy sequencing utilizing T7 sequenase (U.S. Biochemicals, Cleveland, $\mathrm{OH}$ ).

Stable transfection into $G C$ rat pituitary cells. Semiconfluent GC cells in 100-mm dishes were cotransfected by the CaP04 method (18), using a 10:1 ratio of linearized mutant or ${ }^{950} \mathrm{Tyr}$ (WT) IGF-I receptor plasmid to pSV2neo. The cells were shocked $16 \mathrm{~h}$ after incubation with $15 \%$ glycerol for $2 \mathrm{~min}$, washed, and incubated in serum-containing medium for $24 \mathrm{~h}$. Cells were then split 1:6, and neomycin (G418) was added in fresh medium at a concentration of $400 \mu \mathrm{g} / \mathrm{ml}$. Medium was replenished every $72 \mathrm{~h}$. G418-resistant colonies were subcloned and further characterized.

IGF-I binding. Binding of radiolabeled IGF-I was performed in suspension. Cells $\left(10^{6}\right)$ were incubated with ${ }^{125} \mathrm{I}-\mathrm{IGF}-\mathrm{I}$ ( $50,000 \mathrm{cpm}$; sp act $2,000 \mathrm{ci} / \mathrm{mmol}$ ) and increasing concentration of unlabeled IGF-I in a final volume of $1 \mathrm{ml}$ of binding buffer ( $50 \mathrm{mM}$ Hepes buffer, $\mathrm{pH}$ 8.0, $1 \% \mathrm{BSA}, 150 \mathrm{mM} \mathrm{NaCl}, 1.2 \mathrm{mM} \mathrm{MgSO}_{4}$ ) at $15^{\circ} \mathrm{C}$. Specific binding was kept constant at $50,000 \mathrm{cpm}$ per $(0.1 \mathrm{ng} / \mathrm{ml})$ assay. Nonspecific binding was defined as the binding observed in the presence of excess ( $100 \mathrm{nM}$ ) unlabeled IGF-I. At the end of the 3-h incubation period, cells were centrifuged and cell-associated radioactivity was separated from free ${ }^{125}$ I-IGF-I by adding $300 \mu$ of ice-cold dibutylphthalate. Cell-associated radioactivity of the samples was then determined by $\gamma$-counting. Calculation of total bound ligand included the free-labeled ligand.

Immunoprecipitation of IGF-I receptor protein. Confluent cells were rinsed twice with PBS and metabolically labeled at $37^{\circ} \mathrm{C}$ with 0.5 $\mathrm{mCi}\left[{ }^{35} \mathrm{~S}\right]$ methionine $(\mathrm{CSA}, 1,049 \mathrm{ci} / \mathrm{mmol})$ in $5 \mathrm{ml}$ of serum-free methionine-free medium. After $16 \mathrm{~h}$, the cells were lysed in lysis buffer $(0.01 \mathrm{M} \mathrm{NaCl}, 0.5 \%$ deoxycholate, $1 \%$ Triton X-100, $0.1 \%$ SDS, $0.01 \%$ sodium azide, and $1 \mathrm{mM}$ phenylmethylsulfonyl fluoride), and centrifuged at 3,000 rpm for $15 \mathrm{~min}$ at $4^{\circ} \mathrm{C}$. Either $\alpha \mathrm{IR} 3$ or $\mathrm{Ab} \mathrm{1-2}$ were used at 1:500 or a 1:300 final concentrations, respectively. Immune complexes were precipitated with protein A-Sepharose (Pharmacia, Inc., Piscataway, NJ). The pellets were then washed and loaded onto $4 \%$ nondenaturing polyacrylamide SDS gels along with prestained protein molecular weight markers (Bethesda Research Laboratories, Gaithersburg, MD). For studies of the IGF-I receptor biosynthetic half-life, semiconfluent cells were metabolically labeled with $\left[{ }^{35} \mathrm{~S}\right]$ methionine as described. After $16 \mathrm{~h}$, medium was replenished with serum-free defined medium containing methionine with or without $6.5 \mathrm{nM}$ IGF-I. After further incubation at $37^{\circ} \mathrm{C}$, the cells were harvested at the indicated time points and processed as described above.

GH secretion. $5 \times 10^{5}$ cells were plated on $9-\mathrm{cm}^{2}$ multiwells and grown for $24 \mathrm{~h}$ in growth medium. Medium was then aspirated monolayer washed twice with PBS, and replenished with $1.5 \mathrm{ml}$ of serum-free defined medium with or without IGF-I $6.5 \mathrm{nM}$. Aliquots of medium were removed at the indicated time points and assayed for rat $\mathrm{GH}$ using RIA reagents kindly provided by the National Hormone and Pituitary Program, NIDDK (Bethesda, MD).

Tyrosine phosphorylation. Cells labeled with $\left[{ }^{35} \mathrm{~S}\right]$ methionine for $16 \mathrm{~h}$ were washed with PBS and incubated with or without IGF-I (6.5 $\mathrm{nM}$ ) in serum-free medium at $37^{\circ} \mathrm{C}$ for $1 \mathrm{~min}$. Cells were then lysed in lysis buffer ( $1 \%$ Triton X-100, $10 \mathrm{mM}$ Tris, pH 7.6, 5 mM EDTA, pH
$8,50 \mathrm{mM} \mathrm{NaCl}, 30 \mathrm{mM}$ sodium pyrophosphate, $0.1 \%$ BSA, $2 \mathrm{mM}$ sodium orthovanadate, $200 \mathrm{mM}$ PMSF) and centrifuged for $15 \mathrm{~min}$ at $3,000 \mathrm{rpm}$. Proteins were precipitated with a monoclonal anti-phosphotyrosine antibody $\operatorname{Tyr}(\mathrm{Ab}-2)$ for $3 \mathrm{~h}$ at $4^{\circ} \mathrm{C}$. Mouse anti-IgG and protein A sepharose (Pharmacia, Inc.) were incubated with the cell lysate complex for a further $2 \mathrm{~h}$ at $22^{\circ} \mathrm{C}$. Immunoprecipitates were washed six times in lysis buffer, resuspended in sample buffer, heated to $95^{\circ} \mathrm{C}$ for $3 \mathrm{~min}$, and electrophoresed on $7.5 \%$ SDS-polyacrylamide gels.

\section{Results}

GC rat pituitary cells which express $\sim 2 \times 10^{4}$ endogenous IGF-I receptors per cell were transfected with either the intact human IGF-I receptor cDNA, ${ }^{950} \mathrm{Tyr}$ (WT), or a truncated receptor in which a synthetic stop codon was inserted at position ( ${ }^{952}$ STOP) (Fig. 1). Geneticin (G418) was used to select resistant GC cells expressing the transfected plasmids (15). Clones were screened for expression of the human IGF-I receptor by ${ }^{125} \mathrm{I}$-IGF-I binding. Scatchard analysis of selected clones overexpressing either WT or mutant IGF-I receptors is shown in Fig. 1. Binding affinities of the WT and mutant clones $(0.39-0.92 \mathrm{nM})$ were in a similar range to the $K_{d}$ for IGF-I binding to parental untransfected rat cells. Transfected cells had a 14-50-fold increase in IGF-I receptor binding sites, with ${ }^{952}$ STOP transfectants expressing almost $10^{6}$ receptor per cell.

IGF-I receptor immunoprecipitation. Cells expressing either ${ }^{950} \mathrm{Tyr}$ (WT) or mutant receptors were metabolically labeled with $\left[{ }^{35} \mathrm{~S}\right]$ methionine for $16 \mathrm{~h}$ and their IGF-I receptors immunoprecipitated with either a monoclonal antibody recognizing the $\alpha$ subunit of the human IGF-I receptor ( $\alpha$ IR3) or a monoclonal antibody which recognizes both human and rat IGF-I receptor $\beta$-carboxy terminal subunits (Ab 1-2). The small number of nonenriched endogenous receptors derived from untransfected cells failed to recognize either $\alpha$ IR3 or Ab $1-2$, as expected (19). The $460-\mathrm{kD}^{950} \mathrm{Tyr}$ (WT) human holotetramer, the $360-\mathrm{kD}$ rat / mutant human hybrid and $300-\mathrm{kD}$ mutant human holotetramer were recognized in ${ }^{950} \mathrm{Tyr}$ (WT) and ${ }^{952}$ STOP cells respectively (Fig. 2). The intact IGF-I receptor human holotetramer was immunoprecipitated by both $\alpha$ IR3 and antibody Ab 1-2 in ${ }^{950} \mathrm{Tyr}$ (WT) cells as expected. $\alpha$ IR3 precipitated the truncated ( $\left.{ }^{952} \mathrm{STOP}\right)$ human receptor holotetramer, but only $\mathrm{Ab}$ 1-2 recognized the rat/mutant human hybrid receptor. The ratio of hybrid receptors to endogenous rat receptor proteins suggests that the majority of endogenous IGF-I receptors are in hybrid formation with the overexpressed mutant human IGF-I receptors.

IGF-I receptor biosynthetic half-life. ${ }^{950} \mathrm{Tyr}$ (WT) and truncated ${ }^{952}$ STOP transfectants were labeled with $\left[{ }^{35} \mathrm{~S}\right]$ methionine for $16 \mathrm{~h}$. Medium was then changed and pulse chase experiments performed for up to $16 \mathrm{~h}$ in the presence or absence of IGF-I ligand (6.5 nM) (Fig. 3). Half-life of ${ }^{950} \mathrm{Tyr}$ (WT) human receptors was $>6 \mathrm{~h}$. Densitometric scanning reveals a $90 \%$ increase in receptor degradation by $16 \mathrm{~h}$. The addition of ligand appeared not to influence the rate of degradation of the receptors. In cells expressing mutant receptors ( $\left.{ }^{952} \mathrm{STOP}\right)$, hybrid receptor degradation rates were clearly slower, and by $16 \mathrm{~h}$ the majority of synthesized receptors were still present (Fig. 3 $b$ ). Similarly, the presence of ligand did not affect the hybrid receptor half-life. Mutant human IGF-I holotetramers also appeared to degrade at a slower rate, similar to the slow degradation of rat/mutant human hybrid receptors (Fig. $3 c$ ). The apparent reduction in receptor mass in the presence of ligand is 
TRANSFECTED GC CELLS $\quad$ STRUCTURE OF $\beta$ SUBUNIT $\quad$ KINDING
SITES/CELL

(nM) $\quad\left(\times 10^{3}\right)$

\begin{tabular}{|c|c|c|c|c|}
\hline 0 & Untransfected & & 0.66 & 19 \\
\hline \multicolumn{5}{|c|}{ 950Tyr } \\
\hline$\square$ & IGFIR $^{950}$ Tyr (WT) & $\mathrm{NH}_{2} \square \mathbb{U T A}$ & 0.39 & 258 \\
\hline$x$ & IGFIR $^{952}$ STOP & $\mathrm{NH}_{2} \square$ VIIA $\quad{ }_{\mathrm{COOH}}^{952 \mathrm{STOP}}$ & 0.92 & 964 \\
\hline
\end{tabular}

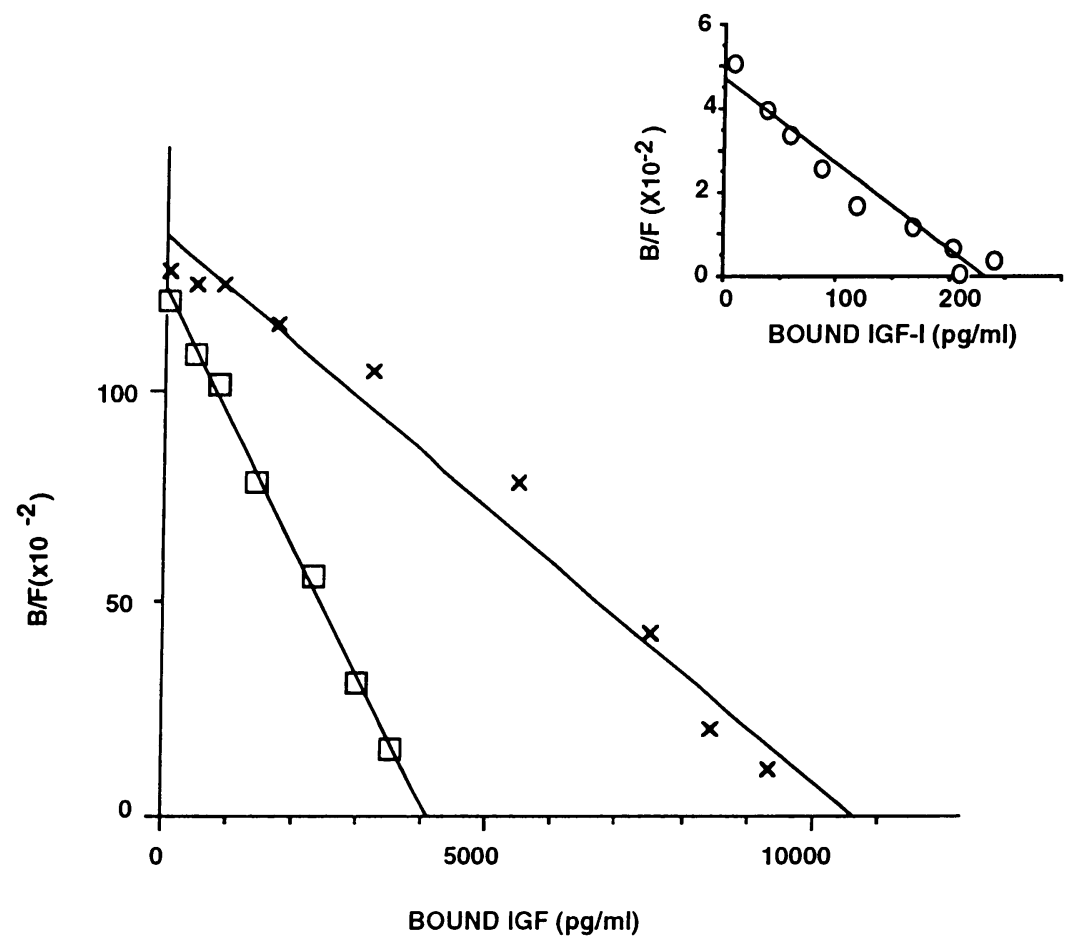

Figure 1. Scatchard analysis of transfectants. IGF-I receptor cDNA constructs ( $\beta$ subunit) utilized for the transfections are depicted. Scatchard analysis with the derived $K_{d}$ and number of binding sites for untransfected, ${ }^{950} \mathrm{Tyr}$ (WT) and ${ }^{952} \mathrm{STOP}$ cell lines is indicated. $K_{\mathrm{d}}={ }^{950} \mathrm{Tyr}(\mathrm{WT})$ $0.39 \pm 0.09,{ }^{952} \mathrm{STOP}$ $0.92 \pm 0.26, P<0.04$ vs. ${ }^{950} \mathrm{Tyr}$.

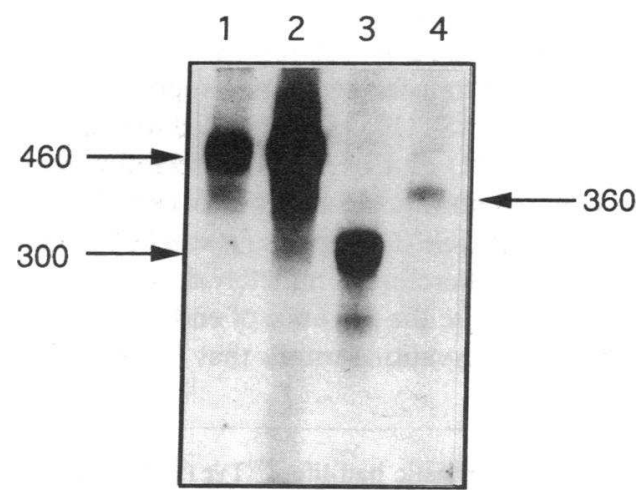

Figure 2. Immunoprecipitation of $\left[{ }^{35} \mathrm{~S}\right]$ methionine labeled IGF-I receptors. ${ }^{950} \mathrm{Tyr}$ (WT) (lanes 1 and 2) or ${ }^{952}$ STOP cells (lanes 3 and 4) were metabolically labeled with $\left[{ }^{35} \mathrm{~S}\right]$ methionine, immunoprecipitated with either Ab 1-2 (lanes 2 and 4) or $\alpha \operatorname{IR3}$ (lanes 1 and 3) and then electrophoresed on a $4 \%$ nondenaturing gel. The $460-\mathrm{kD}$ intact human or rat IGF-I receptor protein, $360-\mathrm{kD}$ rat/mutant human IGF receptor protein, and 300-kD truncated human IGF-I receptor proteins are indicated. due to competition between IGF-I and $\alpha$ IR 3 antibody for binding to the $\alpha$ subunit (19), rather than increased degradation.

Ligand-induced receptor autophosphorylation and phosphorylation of endogenous substrate. Cells expressing either ${ }^{950} \mathrm{Tyr}$ (WT) or truncated receptors were incubated in the presence or absence of IGF-I $6.5 \mathrm{nM}$ for $1 \mathrm{~min}$ at $37^{\circ} \mathrm{C}$. The transfectants were then lysed, immunoprecipitated with monoclonal anti-phosphotyrosine antibody, and electrophoresed on SDS-polyacrymide gels. In the presence of IGF-I, the $\alpha$ and $\beta$ subunits of the IGF-I receptor as well as the predicted pp183 substrate of the receptor were detected in cells overexpressing ${ }^{950}$ Tyr (WT) IGF-I receptors (Fig. 4). The ${ }^{952}$ STOP transfectants failed to undergo ligand-mediated IGF-I receptor autophosphorylation and endogenous protein phosphorylation. $\left[{ }^{35} \mathrm{~S}\right.$ ] methionine labeling of the $\alpha$ subunit is less intense than that of the $\beta$ subunit consistent with the $1: 2$ ratio of methionine residues in the subunits. The $\alpha$ subunit of the IGF-I receptor is immunoprecipitated by anti-phosphotyrosine antibodies despite the absence of phosphorylation on its tyrosine residues because of the disulfide bond between the $\alpha$ and phosphorylated $\beta$ receptor subunits. 

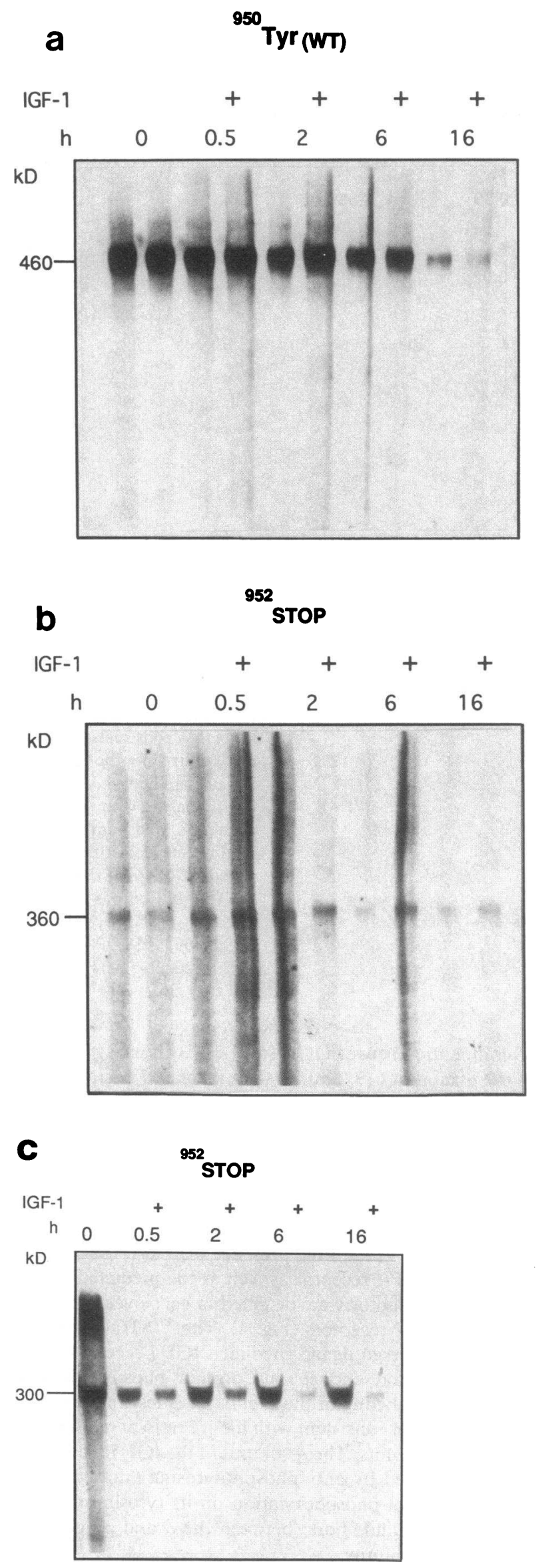

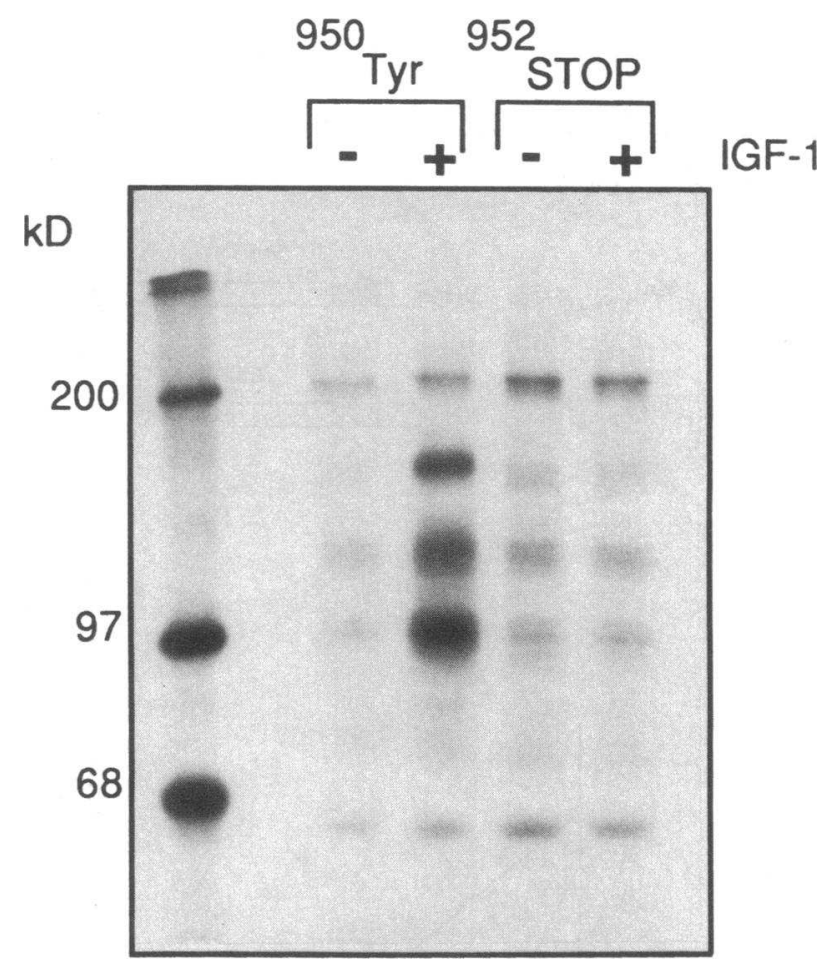

Figure 4. Phosphorylation of tyrosine residues in the IGF-I receptor and cytoplasmic endogenous substrate. Cells expressing either ${ }^{950} \mathrm{Tyr}$ (WT) or ${ }^{952}$ STOP IGF-I receptor were metabolically labeled with $\left[{ }^{35} \mathrm{~S}\right]$ methionine and then treated with IGF-I $6.5 \mathrm{nM}$ for $1 \mathrm{~min}$ at 37C. Cells were lysed, immunoprecipated with a monoclonal antiphosphotyrosine antibody as described, and analyzed on $7.5 \%$ SDS-polyacrylamide gels.

IGF-I receptor signaling. To determine the effect of hybrid receptor formation on endogenous rat IGF-I receptor function, pituitary IGF-I receptor signaling was tested. Cells were treated with IGF-I ( $6.5 \mathrm{nM})$ and $\mathrm{GH}$ secretion measured. After $18 \mathrm{~h}$ of IGF-I treatment, untransfected cells only suppressed GH by $20 \%$, whereas ${ }^{950} \mathrm{Tyr}$ (WT) transfectants already exhibited a $58 \%$ suppression of GH secretion as previously reported (17, 18). ${ }^{952}$ STOP cells failed to suppress GH secretion (Fig. 5). By $36 \mathrm{~h}$, untransfected cells showed a $40 \%$ suppression of $\mathrm{GH}$, and overexpressing ${ }^{950} \mathrm{Tyr}$ (WT) transfectants a $60 \%$ suppression of $\mathrm{GH}$ as expected. However, ${ }^{952} \mathrm{STOP}$ cells still failed to respond to the IGF-I ligand $(6.5 \mathrm{nM})$ and in fact, GH secretion was higher in these cells than in nontransfected control cells despite the presence of endogenous IGF-I receptors $(P<0.001)$. The mutant ${ }^{952}$ STOP cells were therefore completely devoid of biological signaling to GH despite the presence of endogenous rat IGF-I receptors. These observations imply that ${ }^{952}$ STOP be-

Figure 3. IGF-I receptor biosynthetic half-life. ${ }^{950} \mathrm{Tyr}$ (WT) and ${ }^{952} \mathrm{STOP}$ cells were labeled with $\left[{ }^{35} \mathrm{~S}\right]$ methionine for $16 \mathrm{~h}$. Medium was then changed to serum-free defined medium with or without IGF-I (6.5 nM.) Cells were harvested at the indicated time points, receptors were precipitated and $4 \%$ nondenaturing gels used to separate the proteins. Panels $a$ and $b$ depict results of precipitation with antibody 1-2, and panel $c$ depicts results of $\alpha \operatorname{IR} 3$ antibody precipitation. Migration of the expected 460,360 , and $300 \mathrm{kD}$ IGF-I receptor proteins is indicated. Data is from a representative experiment, independently performed three times. 


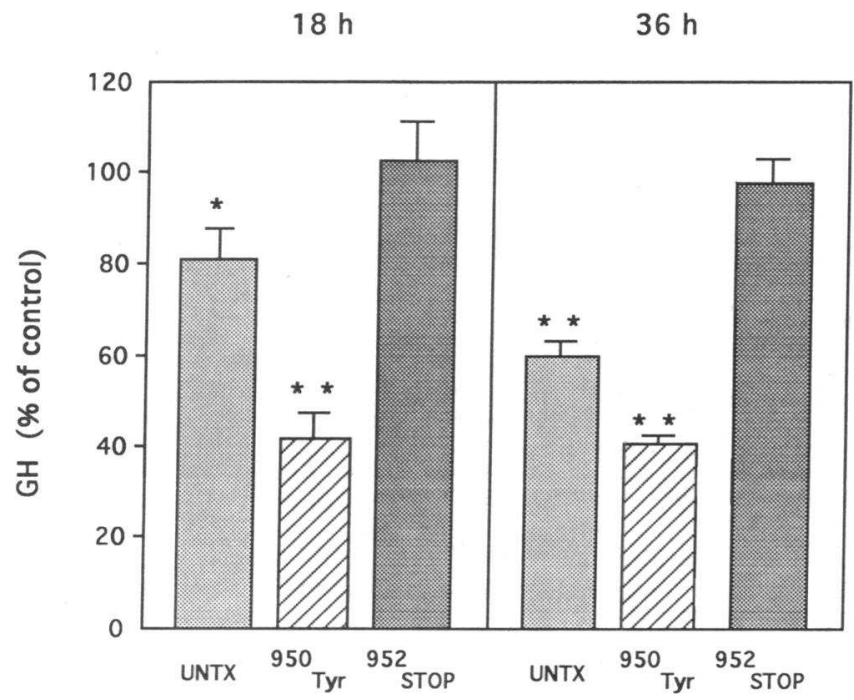

Figure 5. Effects of IGF-I on GH secretion in untransfected (UNTX), ${ }^{950} \mathrm{Tyr}$, and ${ }^{952} \mathrm{STOP}$ cells. $10^{5}$ cells were seeded in $9-\mathrm{cm}^{2}$ dishes as described. Serum-free defined medium was then replenished with or without added IGF-I (6.5 $\mathrm{nM}$ ) and incubations continued for the indicated time periods. Medium was then aspirated and GH levels measured by RIA. GH secretion by control untreated cells $(4.2 \mathrm{ng} /$ $\mathrm{ml}, 100 \%$ at $18 \mathrm{~h}, 12 \mathrm{ng} / \mathrm{ml}, 100 \%$ at $36 \mathrm{~h})(100 \%)$, was compared to effects of IGF-I on GH secretion by the three different cell types. ${ }^{*} P<0.05$ UNTX vs. ${ }^{952}$ STOP; ${ }^{* *} P<0.001$ UNTX vs. ${ }^{952}$ STOP; ${ }^{* *} P$ $<0.001{ }^{950} \mathrm{Tyr}$ vs. ${ }^{952} \mathrm{STOP}$. Results are the mean \pm SEM of three separate experiments.

haves as a dominant negative inhibitor of endogenous IGF-I receptor function.

\section{Discussion}

In this report we describe a model system which allowed analysis of endogenous rat/mutant human hybrid IGF-I receptors, using pituitary cell lines which express a mixed population of ${ }^{950} \mathrm{Tyr}$ (WT) or truncated mutant human IGF-I receptor cDNAs. The size difference between these receptors allows for easy identification of each respective receptor protein. The results indicate that the majority of endogenous rat IGF-I receptors form hybrids with overexpressed mutant human IGF-I receptors. The overexpression of mutant receptors forming hybrids results in dominant inhibition of endogenous IGF-I receptor function as evidenced by loss of endogenous pituitary receptor-mediated $\mathrm{GH}$ inhibition in response to IGF-I in ${ }^{952}$ STOP transfectants.

Newly synthesized rat/mutant human IGF-I hybrid receptors have a prolonged half-life as compared to the ${ }^{950} \mathrm{Tyr}$ (WT) human IGF-I receptor degradation rate. These results indicate that interactions between ${ }^{950} \mathrm{Tyr}$ (WT) and defective half receptors may have an inhibiting influence on the rate of IGF-I receptor degradation. Despite abundant IGF-I binding, the defective human $\alpha \beta$ half-receptors appear to block the ligand-mediated signal transduction of endogenous rat $\alpha \beta$ half-receptors to the GH gene as well as ligand-induced phosphorylation on tyrosine residues by forming nonfunctional hybrids.

The results shown here characterize IGF-I hybrid receptor function in pituitary cells. Preferential hybrid formation between endogenous rat IGF-I receptors and overexpressed mu- tant human IGF-I receptors is consistent with recent studies showing similar hybrid formation of the insulin receptor (1416). Although this study was not aimed at identifying endogenous rat insulin/mutant IGF-I receptor hybrid formation, others have demonstrated that the endogenous rat IGF-I receptor can form a hybrid with human insulin half-receptors (1416). The possible formation of rat insulin/human IGF-I receptors would not alter the interpretation of the present findings. The monoclonal antibody Ab 1-2 was capable of precipitating the rat/human IGF-I hybrid receptors but does not cross-react with insulin receptors (20). The monoclonal human $\alpha$ IR3 antibody bound to human IGF-I receptors, but did not bind to the endogenous rat IGF-I receptors and only bound weakly to the rat/human hybrid. The $360-\mathrm{kD}$ IGF-I receptor protein species precipitated by $\mathrm{Ab}$ 1-2 receptor is probably a receptor hybrid inasmuch as it was not present in cells overexpressing WT receptors which only were manifest as a $460-\mathrm{kD}$ band, as expected.

The lack of an IGF-I inhibitory effect on pituitary GH secretion is coincident with the loss of endogenous wild type rat holotetramers in the cells overexpressing truncated ( ${ }^{952}$ STOP) human IGF-I receptors by the formation of rat/human hybrid receptors. These hybrids are nonfunctional probably due to the fact that they consist of an intact and kinase defective $\alpha \beta$ halfreceptor. These results demonstrate transdominant inhibition of ligand-dependent autophosphorylation and substrate phosphorylation by kinase inactive IGF-I half-receptors and are consistent with similar results shown for the insulin receptor $(13,21)$. Co-expression of a truncated and wild-type plateletderived growth factor $\beta$ receptor abolished receptor autophosphorylation, association of PI-3 kinase with the receptor and calcium mobilization so that the early steps in platelet-derived growth factor signal transduction were blocked (10). Similar dominant negative loss of function has also been reported for truncated epidermal growth factor receptors $(8,9)$ and a point mutant in the kinase domain of c-kit (12).

The dominant negative concept, initially proposed by Herskowitz (22) could be extrapolated to dimeric ligands. Hybrid receptors provide a unique tool to evaluate tetrameric receptor functioning. Based on these results, overexpression of dominant negative IGF-I receptor mutants in transgenic mice may therefore represent a viable technique for targeted inactivation of human pituitary genes.

\section{Acknowledgments}

The authors thank Drs. K. Siddle and M. Soos (Cambridge University) for kindly providing IGF-I receptor antibodies, and Grace G. Labrado for secretarial assistance.

This work was supported by grants DK-34824 (Dr. Melmed) and DK-02023 (Dr. Prager) from the National Institutes of Health.

\section{References}

1. Prager, D., S. Melmed, and J. A. Fagin. 1989. Feedback regulation of growth hormone gene expression by insulin-like growth factor I. In Molecular and Cellular Biology of Insulin-like Growth Factors and Their Receptors. D. Le Roith and M. K. Raizada editors. Plenum Publishing Corp., New York.

2. Yamashita, S., and S. Melmed. 1987. Insulin-like growth factor I regulation of growth hormone gene transcription in primary rat pituitary cells. J. Clin. Invest. 449-452.

3. Yamasaki, H., D. Prager, S. Gebremedhin, L. Moise, and S. Melmed. 1991. Binding and action of insulin-like growth factor I in pituitary tumor cells. Endocrinology. 128:857-862. 
4. Forman, B. M., C. R. Yang, M. Au, J. Casanova, J. Ghysdel, and H. H. Samuels. 1989. A domain containing leucine-zipper like motifs mediate novel in vitro interactions between the thyroid hormone and retinoic acid receptors. $\mathrm{Mol}$. Endocrinol. 3:1610-1626.

5. Chatterjee, V. K. K., T. Nagaya, L. D. Madison, S. Datta, A. Rentoumis, and J. L. Jameson. 1991. Thyroid hormone resistance syndrome: inhibition of normal receptor function by mutant thyroid hormone receptors. J. Clin. Invest. 87:1977-1984.

6. Damm, K., C. C. Thompson, and R. M. Evans. 1989. Protein encoded by v-erbA functions as a thyroid hormone receptor agonist. Nature (Lond.) 339:593-597.

7. Taylor, S. I., A. Cama, D. Accili, F. Barbetti, E. Imano, H. Kadowaki, and T. Kadowaki. 1991. Genetic basis of endocrine disease. 1. molecular genetics of insulin resistant diabetes mellitus. J. Clin. Endocrinol. Metab. 73:1158-1163.

8. Basu, A., M. Raghunath, S. Bishayee, M. Das. 1989. Inhibition of tyrosine kinase activity of the epidermal growth factor receptor by a truncated receptor from that binds to EGF: role for interreceptor interaction in kinase regulation. Mol. Cell. Biol. 9:671-677.

9. Honegger, A. M., T. J. Dull, S. Felder, E. Van Obberghen, F. Bellot, D. Szapary, A. Schmidt, and J. Schlessinger. 1987. Point mutation at the ATP binding site of EGF receptor abolishes protein-tyrosine kinase activity and alters cellular routing. Cell. 51:199-209.

10. Ueno, H., H. Colbert, J. A. Escobedo, and L. T. Williams. 1991. Inhibition of PDGF $\beta$ receptor signal transduction by coexpression of a truncated receptor. Science (Wash. DC). 252:844-252.

11. Amaya, E., T. J. Musci, and M. W. Kirschner. 1991. Expression of a dominant negative mutant of the FGF receptor disrupts mesoderm formation in Xenopus embryos. Cell. 66:257-270.

12. Reith, A. D., R. Rottapell, E. Giddens, C. Brady, L. Forrester, and A. Bernstein. 1990. W mutant mice with mild or severe development defects contain distinct point mutations in the kinase domain of the c-kit receptor. Genes Dev. 4:390-400.
13. Maegawa, H., J. M. Olefsky, S. Thies, D. Boyd, A. Ullrich, and D. A. McClain. 1988. Insulin receptors with defective tyrosine kinase inhibit normal receptor function at the level of substrate phosphorylation. J. Biol. Chem. 263:12629-12637.

14. Soos, M. A., J. Whittaker, R. Lammers, A. Ullrich, and K. Siddle. 1990. Receptors for insulin and insulin-like growth factor-I can form hybrid dimers. Biochem. J. 270:383-390.

15. Soos, M. A., and K. Siddle. 1989. Immunological relationships between receptors for insulin and insulin-like growth factor I. Biochem. J. 263:553-563.

16. Chin, J. E., J. M. Tavare, L. Ellis, and R. A. Roth. 1991. Evidence for hybrid rodent and human insulin receptors in transfected cells. J. Biol. Chem. 266:15587-15590.

17. Yamasaki, H., D. Prager, S. Gebremedhin, L. Moise, and S. Melmed. 1991. IGF-I attenuation of growth hormone is enhanced by over-expression of pituitary cell IGF-I receptors. Mol. Endocrinol. 5:890-896.

18. Yamasaki, H., D. Prager, S. Gebremedhin, and S. Melmed. 1992. Human insulin-like growth factor I receptor ${ }^{950}$ tyrosine is required for somatotroph growth factor signal transduction. J. Biol. Chem. In press.

19. Gustafson, T. A., and W. J. Rutter. 1990. The cysteine-rich domains of the insulin and insulin-like growth factor I receptors are primary determinants of hormone binding. J. Biol. Chem. 265:18663-18667.

20. Soos, M. A., C. E. Taylor, R. Lammers, A. Ullrich, and K. Siddle. 1991. Monoclonal antibodies for studying the structure and function of Type I IGF receptors and IGF receptor/insulin receptor hybrids. In Modern Concepts of Insulin-like Growth Factors. E. M. Spencer, editor Elsevier Science Publishing Co., New York. 461-471.

21. Treadway, J. L., B. D. Morrison, M. A. Soos, K. Siddle, J. Olefsky, A. Ullrich, D. A. McClain, and J. E. Pessin. 1991. Transdominant inhibition of tyrosine kinase activity in mutant insulin/insulin-like growth factor I hybrid receptors. Proc. Natl. Acad. Sci. USA 88:214-218.

22. Herskowitz, I. 1987. Functional inactivation of genes by dominant negative mutations. Nature (Lond.). 329:219-222. 